\title{
ABUNDANCE AND DIVERSITY OF SOIL MACROINVERTEBRATES IN SUGARCANE (SACCHARUM SPP.) PLANTATIONS UNDER ORGANIC AND CHEMICAL FERTILIZATION IN BELIZE
}

\section{ABUNDANCIA Y DIVERSIDAD DE MACROINVERTEBRADOS DE SUELO EN EL CULTIVO DE CAÑA DE AZÚCAR (SACCHARUM SPP.) BAJO FERTILIZACIÓN ORGÁNICA Y QUÍMICA EN BELICE}

\author{
LUCIANO CHI ${ }^{1}$, ESPERANZA HUERTA-LWANGA ${ }^{1}$, DAVID ÁLVAREZ-SOLÍS ${ }^{2}$, VÍCTOR MANUEL KÚ-QUEJ ${ }^{1}$, \\ JORGE MENDOZA-VEGA ${ }^{1 *}$

\begin{abstract}
${ }^{1}$ Department of Agriculture, Society and Environment, El Colegio de la Frontera Sur, Avenida Rancho Polígono 2-A, Col. Ciudad Industrial, C.P. 24500, Lerma, Campeche, Mexico.<lchi@ecosur.edu.mx>; <ehuertaecosur@gmail.com>; <vmku@ecosur.mx>; $<$ jmendoza@ecosur.mx>

${ }^{2}$ Department of Agriculture, Society and Environment, El Colegio de la Frontera Sur, Carretera Panamericana y Periférico Sur s/n., C.P. 29290, San Cristóbal de Las Casas, Chiapas, Mexico.<dalvarez@ecosur.mx>

*Corresponding author: <jmendoza@ecosur.mx>
\end{abstract}

Received: 18/10/2017; accepted: 30/04/2020; published online: 16/06/2020

Responsible editor: Carmen Huerta

Chi, L., Huerta, E., Álvarez-Solís, D., Kú-Quej, V., Mendoza-Vega, J. (2020) Abundance and diversity of soil macroinvertebrates in sugarcane (Saccharum spp.) plantations under organic and chemical fertilization in Belize. Acta Zoológica Mexicana (nueva serie), 36, 1-19. https://doi.org/10.21829/azm.2020.3611106

\begin{abstract}
Many studies suggest that sugarcane management practices have negative impact on soil quality, especially on soil organisms, however, information on macroinvertebrate abundance and diversity in conventional sugarcane fields is scarce. This study determined the abundance and diversity of soil macroinvertebrates in sugarcane plantations under 2 types of soils, Cambisol and Fluvisol, with three types of fertilizer management: chemical fertilizer, vinasse and filter mud, and in a secondary forest (on a Cambisol). Sampling was carried out in northern Belize during two crop cycles (from May 2013 to May 2015). Soil macroinvertebrates were collected using monoliths based on Tropical Soil Biology and Fertility (TSBF) Handbook of Methods at the end of the rainy seasons. The parameters evaluated were biomass, density and diversity of soil macroinvertebrates (number of morphospecies, an ecological index for tropical soil quality based on macrofauna, and a converted Shannon index (H_exp)), yield and plant response variables (number of stool, number of stem, number of active leaves, stem length and stem diameter). A total of 7,634 individuals were identified, grouped into 52 morphospecies belonging to 16 orders and three species of annelids. No significant differences existed among management systems (application of chemical fertilizer, vinasse, filter mud and secondary forest) on abundance and diversity of soil macroinvertebrates, yield and plant variables. However, there were significant differences between soils and cycles in some evaluated parameters. Presuming that soil type and seasonal conditions, in a two years trial, had higher weight on determine the studied parameters than the different management systems.
\end{abstract}

Key words: soil macro-organisms; filter mud; organic versus inorganic fertilization; vinasse 
Chi, L., Huerta, E., Álvarez-Solís, D., Kú-Quej, V., Mendoza-Vega, J. (2020) Abundancia y diversidad de macroinvertebrados de suelo en el cultivo de caña de azúcar (Saccharum spp.) bajo fertilización orgánica y química en Belice. Acta Zoológica Mexicana (nueva serie), 36, 1-19.

https://doi.org/10.21829/azm.2020.3611106

RESUMEN. Muchos estudios sugieren que las prácticas de manejo de la caña de azúcar tienen un impacto negativo en la calidad del suelo, especialmente en los organismos del suelo, sin embargo, la información sobre la abundancia y diversidad de macroinvertebrados en los campos de caña de azúcar convencionales es escasa. Este estudio determinó la abundancia y diversidad de macroinvertebrados del suelo en plantaciones de caña de azúcar en dos tipos de suelo, Cambisol y Fluvisol, tres tipos de manejo de fertilizantes: fertilizante químico, vinaza, cachaza, y en un bosque secundario (en un Cambisol). El muestreo fue llevado a cabo en el norte de Belice durante dos ciclos agrícolas (de mayo 2013 a mayo 2015). Los macroinvertebrados del suelo fueron colectados usando monolitos basados en el método del Manual de Métodos Tropical Soil Biology and Fertility (TSBF) al final de las temporadas de lluvia. Los parámetros evaluados fueron biomasa, densidad y diversidad de macroinvertebrados del suelo (número de morfoespecies, un índice ecológico para la calidad del suelo tropical y un índice de Shannon convertido (H_exp)), rendimiento y variables de las plantas (número de cepas, número de tallos, número de hojas activas, largo del tallo y diámetro del tallo). Un total de 7,634 individuos fueron identificados, agrupados en 52 morfoespecies pertenecientes a 16 Ordenes y tres especies de anélidos. No existió diferencias significativas entre los sistemas de manejo (aplicación de fertilizante químico, vinaza, cachaza y bosque secundario) en la abundancia y diversidad de macroinvertebrados, rendimiento y variables de las plantas. Sin embargo, hubo diferencias significativas entre suelos y ciclos en algunos de los parámetros. Suponiendo que el tipo de suelo y las condiciones estacionales, en un ensayo de dos años, tuvieron mayor peso para determinar los parámetros estudiados que los diferentes sistemas de manejo.

Palabras clave: macro-organismos del suelo; cachaza; fertilización orgánica versus inorgánica; vinaza

\section{INTRODUCTION}

Sugarcane production continues to be the main agricultural activity in Belize, making a significant contribution to the agricultural sector, national income and foreign exchange earnings: $7.8 \%$ of gross domestic product (GDP), $10 \%$ of jobs and $6 \%$ of foreign exchange earnings (Statistical Institute of Belize, 2015). However, the current sugarcane management system is unsustainable (Chi et al., 2017), due to the inefficient fertilizer and herbicide application as well as inappropriate cultivation and harvesting practices which leads to soil degradation (Geissen et al., 2009), environmental deterioration, detrimental effects on soil and water quality, and nutritional imbalance (De León \& Gonzalez, 2011).

Intensive agricultural systems such as sugarcane monoculture has also clearly negative impacts on biodiversity conservation (Malézieux et al., 2009), including soil macroinvertebrates populations (Huerta et al., 2006). Thus, it reduces taxonomic richness, density and biomass, indicating high disturbance level of the edaphic environment due to land use intensity, like tillage or fertilizer (Gardi et al., 2002; Cabrera et al., 2011). For instance, in Cuba, Cabrera et al. (2011) report higher densities and biomass of soil macroinvertebrates for secondary forests in comparison to sugarcane monoculture; and Paoletti (1999) and Siqueira et al. (2016) found that earthworms, myriapods and other invertebrates are sensitive to toxic effects of agro-chemicals. Moreover, soil types can also influence local diversity of edaphic macroinvertebrates (Mathieu et al., 2005). In Belize, the sugarcane industry ignores the impact that agricultural inputs and management could have on the environment and more specifically on soil macroinvertebrates.

During recent years renewed scientific attention has propelled evaluation of soil quality bioindicators due to concerns of soil degradation and the need for a sustainable management of soils (Shukla 
et al. 2006; Barrios, 2007; López et al., 2011), through evaluation of relation between soil land use and soil macroinvertebrates (Barros et al., 2002; Mathieu et al., 2005; Velasquez et al., 2007), allowing an ecological dynamic balance and biodiversity (Lang-Ovalle et al., 2010). Siqueira et al. (2016) indicates that soil macrofauna may be used as ecological indicators of agriculture practices since they are very sensitive to both chemical and physical soil parameters. Thus, in the search of a sustainable agriculture in sugarcane production soil macroinvertebrates are required to be included as a soil quality indicator.

Diverse processes occurring in the soil are mediated by organisms that lives on it, such as macroinvertebrates (Lavelle et al., 2006), which includes a great variety of edaphic organisms larger than 2 $\mathrm{mm}$ in size (Baretta, 2006; Bardgett \& van der Putten, 2014). In this regard, macroinvertebrates are important in soil ecosystems for their capacity to decompose organic matter, forming complex food webs essential to a functioning ecosystem (Barnes et al., 2016), as well as supporting most agriculture production systems (production services) through beneficial services that they mediate: soil formation, nutrient cycling and primary production (Lavelle et al., 2006). Moreover, they intervene in soil processes: infiltration, aeration; as well as aggregation, texture (Siqueira et al., 2016), chemical and nutritional properties, and can serve as soil fertility quality bioindicators (Mummey et al., 2002). On the other hand, soil macroinvertebrate communities in each habitat are determined by management practices (physical perturbation, residue distribution, amendments and vegetation) (Bardier, 2005) since their response to changes occurs quickly (Correia \& Oliveira, 2000). Hence, sustainable soil land use and management of sugarcane fields can improve or alter the abundance, diversity and richness of these organism.

Filter mud is a by-product from sugarcane industries and characterized as a soft, spongy, amorphous, and dark brown to brownish material (Ghulam et al., 2012). Generally, for every $100 \mathrm{t}$ of sugarcane crushed, about 3 t of filter mud is produced as a by-product (Gupta et al., 2011). During the 20152016 crop cycle, the sugar industry in Belize produced 38,775.36 t of filter mud (Sugar Cane Production Committee (SCPC), 2015). Likewise, vinasse, obtained from fermentation and distillation of alcohol, which is acidic in nature, dark brown in color with unpleasant odour, possess a high chemical oxygen demand (COD), and biological oxygen demand (BOD) (Dotaniya et al., 2016). In Belize vinasse is produced by two small distilleries which operate seasonally, depending on consumption, but on average, about 10-18 liters of vinasse is obtained per liter of produced alcohol, giving a total production for the industry of $4,400 \mathrm{~m}^{3}$ per year (personal communication, Belize Sugar Industries, 2017). They can improve soil chemical, physical and biological properties, thus enhancing crop quality and yield (Dotaniya et al., 2016, Lang-Ovalle et al., 2010). Also, they can favor humidity retention, microorganism's activation (Neugebaver et al., 1992), as bio-fertilizers (Rodríguez, 1994; Vandevivere \& Ramírez, 1995), improve soil texture and aggregation (Mojica et al., 1994) and contribute to the conservation of natural resources by recycling carbon and mineral elements (Prado et al., 2013).

Thus, direct effects of organic waste from the sugarcane industry on soil chemical properties are increased nitrogen, phosphorus, and calcium concentrations, increased cation exchange capacity (CEC), hence playing a fundamental role in agricultural production, in the maintenance of soil fertility, and as a soil conditioner (Rossetto et al., 2008). These important aspects have been widely discussed among researchers (Barnes et al., 2016), thus Jones et al. (1994) associated termites to soil carbon cycle and soil fertility level; while Subbler et al. (1998), Lang-Ovalle et al. (2010) and Blouin et al. (2013) indicated that earthworms improve soil structure and porosity of agriculture soils.

Regardless the indispensable role of soil macroinvertebrates in soil management, few studies related to sugarcane production have been conducted (Pasqualin et al., 2012; Benazzi et al., 2013). Therefore, the aim of the present study was to determine the abundance and diversity of soil macroinvertebrates in sugarcane plantations under different managements with chemical fertilizers and organic amendments, under the following hypothesis "the chemical fertilizers used in the production of sugarcane have a negative impact on the abundance and diversity of macroinvertebrates", and predictions: "the abundance and 
diversity of soil macroinvertebrates in the soil of sugarcane plantations treated with organic amendments (vinasse and filter mud) will be higher than in the soils treated with agrochemicals".

\section{MATERIALS AND METHODS}

Description of study sites. The study was conducted in northern Belize (Figure $1 ; 18^{\circ} 00^{\prime}$ and $18^{\circ} 30^{\prime} \mathrm{N}$ and $88^{\circ} 34^{\prime}$ and $88^{\circ} 39^{\prime}$ W) with prevailing climate according to Köppen classification system and modified by Garcia (2004) as warm sub-humid (Aw), with rains in summer and a dry season in winter. Specifically, the area falls within the Ax' $\left(\mathrm{w}_{1}\right)$ climate subtype, intermediate between the wettest and the driest of the subhumid classes (Garcia, 2004), with a mean annual long-term rainfall and temperature of 1,053.33 $\mathrm{mm}$ and $26^{\circ} \mathrm{C}$, respectively.

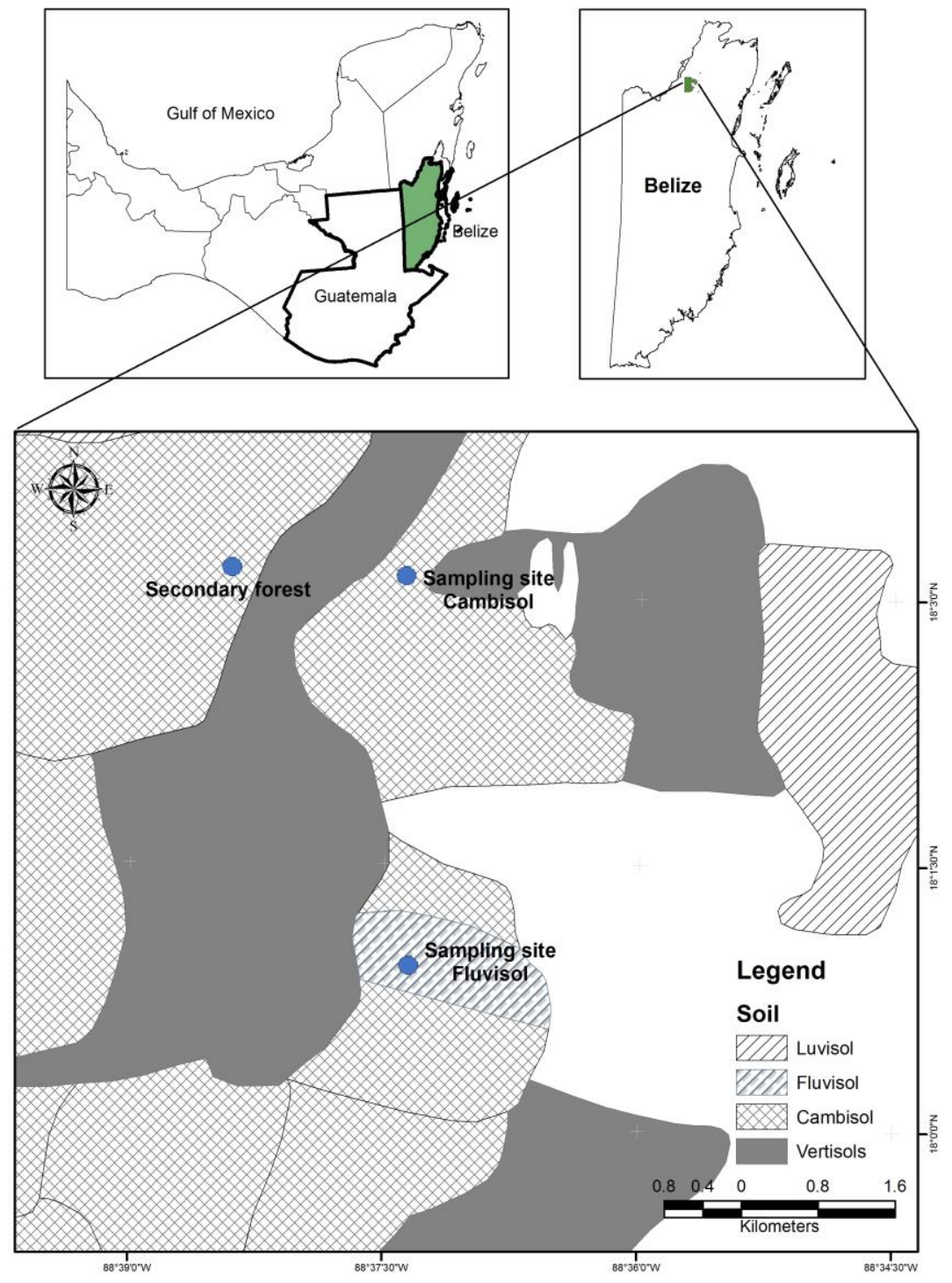

Figure 1. Location of the study sites in northern Belize. 
The study lasted two crop cycles (12 months cycle), from May 2013 to May 2015, and on two sites belonging to American Sugar Refinery/Belize Sugar Industries (ASR/BSI), with different soil types; that are superficial red young Cambisol and Fluvisol (WRB, 2014). In addition, one plot of secondary forest, (undisturbed for more than 15 years), on a Cambisol (WRB, 2014) was also selected as an extra control. It is important to mention that the secondary forest was managed in the past under conventional sugarcane, including application of chemical fertilizer.

Fluvisols are very young soils with weak horizon differentiation and may contain high natural fertility which allows cultivation of a wide range of crops from dryland (WRB, 2014); however flood control, drainage or irrigation are required (Driessen \& Dudal, 1989); it present a dark coarse-textured topsoil $(<15 \%$ clay), grey medium or fine textured subsoil over weathering limestone and is locally known in Belize as 'Pixoy' (King et al., 1992). On the other hand, Cambisols are young soils, this means, they are not highly weathered, what is verified with beginning horizon differentiation through changes in color, structure or texture. They are derived from material with moderate mineral reserves found over calcareous material, medium OM content (De León \& Gonzales, 2011) and are locally known as 'Lazaro clay' (King et al., 1992). Cambisols are commonly used in a wide variety of agricultural crops (Driessen \& Dudal, 1989).

Establishment and management of experimental fields. The sugarcane crops were established during the spring planting period, that is late May to June, and harvested toward the end of the following two crop cycles at 12 months. Land and soil preparation involved removing vegetative material and preparing a tilth adequate for cane emergence and growth. This activity involved five operations; sub-soiling, ploughing (18, 34" discs), harrowing (24 discs), furrowing and bed formation, after which the cane was planted manually. The present investigation was part of a larger fertilization research with crop-yield purposes, where 11 doses of chemical fertilizer, 11 doses of chemical fertilizer combine with vinasse, and 11 doses of chemical fertilizer combine with filter mud were tested. In the present study, sugarcane plots were selected under three different management systems; application of chemical fertilizer (11 different doses of macro elements: N-P-K: 0-20-0; 0-20-100; 0-0-100; 40-10-150; 40-20-50; 40-30-50; 80-0-100; 80-0-0; 80-20-100; 80-20-0; and 120-10-50), vinasse (10 $\left.\mathrm{m}^{3} \mathrm{ha}^{-1}\right)$, and filter mud $\left(50 \mathrm{~m}^{3} \mathrm{ha}^{-1}\right)$. A control without any chemical fertilizer nor organic amendments was also established. Furthermore, a secondary forest, located close to the sugarcane crops, was also sampled. Both vinasse and filter mud doses used in the study resulted from recommendations of previous works from ASR/BSI consultancies.

In the sugarcane plots a randomized complete block design with 4 repetitions were used giving a total of 56 experimental units (EU) per site and cycle. 44 with chemical fertilizer (11 different doses (see above) X 4 repetitions), 4 EU for vinasse and filter mud respectively (1 dose X 4 repetitions) and 4 EU for control. Each EU consisted of 4 rows of $10 \mathrm{~m}$ long and 6 meters wide, being the 2 central rows the sampling unit (SU). The net area per EU was $60 \mathrm{~m}^{2}$; giving a gross area of $3,360 \mathrm{~m}^{2}$ and a net area of $1,680 \mathrm{~m}^{2}$. The distance of ridges between furrows was $2 \mathrm{~m}, 1.5 \mathrm{~m}$ row width and $0.7 \mathrm{~m}$ walkway.

Filter mud is rich in N (1.67\%), P (2.4\%) and OM (52.5\%) (Aloma, 1973; Prado \& Jaramillo, 2006; Melchor et al., 2008; CATS, 2012; Cifuentes et al., 2011). For application it was transported on a fertilizer spreader hauled by tractor and applied directly on top of the setts of the sugarcane study plots. In our study, the filter applied mud came from ASR/BSI sugar factory.

Vinasse is rich in $\mathrm{K}, \mathrm{Ca}(0.05 \%)$ and $\mathrm{Mg}(0.0129)$ (Dotaniya et al., 2016). It was transported on cistern type container hauled and operated by a tractor and applied directly on top of the sets.

Macroinvertebrates and soil sampling methodology. In 2013 and 2014 at the end of the rainy season when macroinvertebrates activity is at its highest, since during low humidity earthworms are dormant (Huerta $e t$ al., 2008), according to the Soil Biology and Fertility (TSBF) method (Anderson \& Ingram, 1993), a 
monolith of $25 \times 25 \times 30 \mathrm{~cm}$ was dug on the SU in each EU; whereas, in secondary forest three $40 \mathrm{~m}$ line transects were established at $60 \mathrm{~m}$ from each other for a total of 5 samples (monoliths) per transect $(8 \mathrm{~m}$ between each sample) giving a total of 15 monoliths per sugarcane cycle (2013-2014). A total of 254 monoliths; 56 monoliths at two sites, two per cycle (56 plots/site x 2 site x 2 cycles) in the sugar cane plantation and 30 monoliths for secondary forest ( 3 transect $\times 5$ samples per transect $\mathrm{x} 2$ cycle) were performed. From the soil of each monolith soil macroinvertebrates (organisms $>2 \mathrm{~mm}$ in size) where collected by hand sorting (meticulously checked on site). They were placed in plastic containers with $96 \%$ alcohol for earthworms and 76\% alcohol for the rest of macroinvertebrates (insects, arachnids, gastropods) to carry to the laboratory. Each container was labelled to know from which monolith and treatment they come from.

Soil macroinvertebrates handling. The soil macroinvertebrates were characterized by their abundance, biomass and diversity. The counting, weighing and classification were performed at the Sugar Industry Research and Development Institute (SIRDI) laboratory in Belize. The method for quantifying soil macroinvertebrates was through direct observation (Williams, 1987), they were identified with the aid of a stereoscope and weighed in an electronic balance $(0.01 \mathrm{~g}$ precision). For macroinvertebrates from the Arthropoda and Mollusca Phylum, identification was done up to morphospecies using Gibb and Oseto (2006) key and for earthworms the James (1994) key.

The soil biological properties investigated in this study were: macroinvertebrate morphospecies, macroinvertebrate biomass $\left(\mathrm{g} . \mathrm{m}^{2}\right)$, macroinvertebrate density $\left(\right.$ ind. $\left.\mathrm{m}^{2}\right)$, ecological index for tropical soil quality based on macrofauna (hereafter soil quality index) (Huerta et al., 2009) and a conversion of the Shannon diversity index (hereafter Shannon_exp index). The presence of soil invertebrates can be used as an indicator of soil quality (Klemens et al., 2003; Ruiz-Camacho, 2004; Lavelle et al., 2006), therefore, under this premises the soil quality index based on macrofauna is an index based on the presence/absence of different groups of soil macrofauna to determine the ecological quality of soils (Huerta et al., 2009). This index considered the number of earthworm species, number of native earthworm species, presence of epigeic earthworms, and presence/absence of litter decomposers from the Order Diplopoda, Isopoda, Coleoptera, Heteroptera and Orthoptera, which integrate the structure of macrodecomposer community. This information is combined with the biomass of earthworms and is passed through a set of rules that determines the soil quality index (Fig. 2) (Huerta et al., 2009). The Shannon diversity index is a commonly used method of measuring species diversity (Stiling, 1999). It assumes that all species from the community are represented in a randomly collected sample. The formula used is: $\mathrm{H}=-\sum_{\mathrm{i}=1}^{\mathrm{S}} \mathrm{p}_{\mathrm{i}} \ln \mathrm{p}_{i}$. Where $p$ is the proportion of individuals in the ith species. Error arises from not including all species of the community in the sample. Therefore, the conversion of the Shannon index values to an effective number of species is recommended to represent diversity in a more reliable way (Jost, 2006). Thus, the values resulted from the Shannon diversity were converted as following: $\exp \left(-\sum_{\mathrm{i}=1}^{\mathrm{S}} \mathrm{p}_{\mathrm{i}} \ln \mathrm{p}_{i}\right)($ Jost, 2006).

Soil characterization of plant macronutrients. In each monolith, both on sugarcane fields and secondary forest, $500 \mathrm{~g}$ of soil was collected (Bautista et al., 2011) with the purpose of characterize the status of plant macronutrients (N, P, and K) in the soils under study. Soil samples were placed in labelled plastic bags, and dried in the shade, sieved and sent to soil laboratory for analysis. In total, 127 loose samples (56 plots/site $\mathrm{x} 2$ sites) for sugarcane fields, and 15 loose samples for secondary forest ( 3 transect x 5 samples per transect) were collected and processed. The methods used to determine the plant macronutrients were: Total $\mathrm{N}$ by micro-Kjeldahl; $\mathrm{K}$ by extraction with ammonium acetate at $\mathrm{pH} 7$ and $\mathrm{P}$ by the Olsen method (Olsen \& Summers, 1982); according to NOM-021-RECNAT-2000 (Norma Oficial Mexicana (NOM), 2002).

Plant variables. As reference of the response to the different types of fertilizers for crop yield, the following plant variables were measured: yield $\left(\mathrm{t} \mathrm{ha}^{-1}\right)$, number of stools $\left(\mathrm{stool} / \mathrm{m}^{2}\right)$, (number of stems $(\mathrm{stem} / \mathrm{m})$, number of active leaves (leaf/plant), stem length $(\mathrm{cm})$ and stem diameter $(\mathrm{cm})$. 


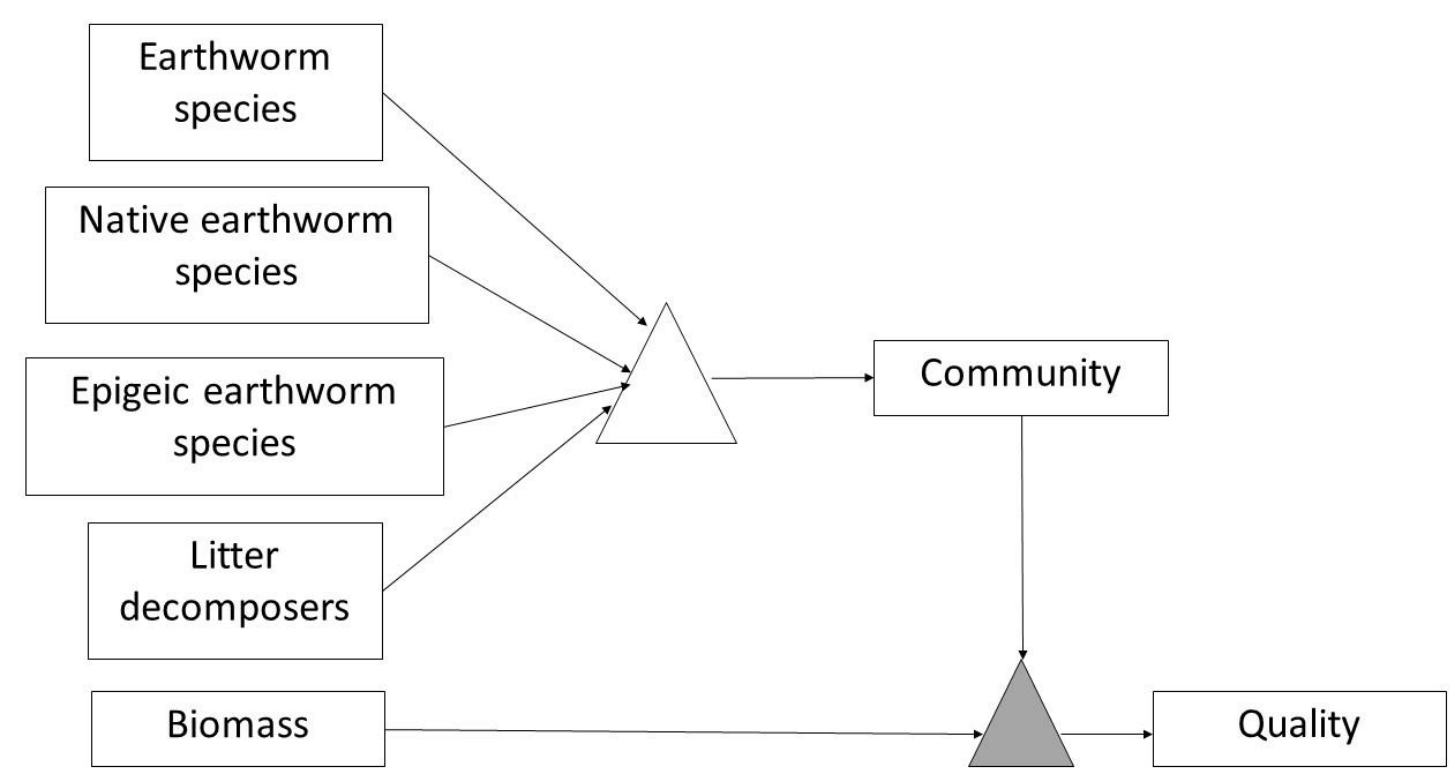

Figure 2. Schematic structure with factors considered in the model to calculate the soil ecological quality index based on soil fauna. Total earthworm species number, number of native earthworm species, presence of epigeic earthworm species and presence of macroinvertebrate litter decomposers are aggregated to the transitory variable "community" by a rule node (white triangle); community and earthworm biomass are aggregated to the soil quality index by a fuzzy rule node (grey triangle) (adapted from Huerta et al., 2009).

Statistical Analysis of data. In order to test differences among the different management systems (chemical fertilizer, vinnase, filter mud, and secondary forest), on soil macroinvertebrates parameters (density, biomass, number of morphospecies), ecological index for tropical soil quality, Shannon_exp index and; plant variables, one-way ANOVA followed by post hoc analysis means test was done (Tukey, $\mathrm{p}<0.05$ ) after testing normality. It was as well tested differences between soil type and cycle, on the same parameters, as well on the macronutirients (N, P, K), this only between soil types, using t-test analysis (Minitab ${ }^{\circledR}$ version 17).

To identify relatedness among soil macroinvertebrates variables with the soil quality index, Shannon_exp index and sugarcane yield a principal component analysis (PCA) was performed including treatments (management systems), soil type and sampling cycles.

\section{RESULTS}

In the present study a total of 7,634 macroinvertebrate individuals, from the 254 monoliths, were identified and grouped in morphospecies (Table 1). The edaphic macroinvertebrate community was characterized by the presence of different annelids, arthropods and mollusc groups. From the total, annelids were the Phylum with the highest number of individuals with 4,461 (58\%).

The identified morphospecies belonged to 15 different Taxa including Aranea, Blattodea, Chilopoda, Colembola, Coleoptera, Dermaptera, Diptera, Diplopoda, Gasteropoda, Hemiptera, Homoptera, Hymenoptera, Isoptera, Orthoptera, Thysanoptera, and one not identified from the Phylum Mollusca (Table $1)$. 
Arthropoda Phylum showed higher abundance for Hymenoptera in sugarcane fields with $38 \%$, while Coleoptera 16.4\%, Blattodea 11.7\%, Chilopoda 9.7\% and Araneae 8.8\%; only the more abundant are enlisted here $(\mathrm{n}=576)$. On the other hand, on secondary forest, Coleoptera showed higher abundance with $23.5 \%$, while Hymenoptera scored 22.7\%, Isoptera $12.1 \%$, Gasteropoda $9.1 \%$ and Aranea $6.8 \%(\mathrm{n}=60)$ (Table 1).

Three species of annelids from the Subclass Oligochaeta were determined Dichogaster saliens, Dichogaster bolaui and Pontoscolex corethrurus; the most abundant was Dichogaster saliens, which along with Dichogaster bolaui are both epigeic and exotic; while Pontoscolex corethrurus endogeic and exotic (Table 1).

Table 1. Classification of soil macroinvertebrates identified in 254 monoliths during 2013-2105 crop cycles grouped according to morphological differences (body form, size and color) from related species in sugarcane fields and secondary forest in Belize.

\begin{tabular}{|c|c|c|c|c|c|c|c|c|c|}
\hline \multirow{2}{*}{ Phylum } & \multirow{2}{*}{ Class } & \multirow{2}{*}{ Order } & \multirow{2}{*}{ Family } & \multirow{2}{*}{ Gender } & \multirow{2}{*}{ Species } & \multicolumn{2}{|c|}{ Sugarcane } & \multicolumn{2}{|c|}{$\begin{array}{c}\text { Secondary } \\
\text { Forest }\end{array}$} \\
\hline & & & & & & $\begin{array}{c}\text { \# of } \\
\text { msp* }\end{array}$ & $\begin{array}{l}\text { \# of } \\
\text { ind }\end{array}$ & $\begin{array}{c}\text { \# of } \\
\text { msp* }\end{array}$ & $\begin{array}{l}\text { \# of } \\
\text { ind* }\end{array}$ \\
\hline \multirow{3}{*}{ Annelida } & \multirow{3}{*}{ Clittelata } & \multirow{3}{*}{ Oligochaeta } & & Dichogaster & D. saliens & $N A$ & 2419 & $N A$ & 9 \\
\hline & & & Acanthodrilidae & Dichogaster & D. balaui & $N A$ & 39 & $N A$ & 4 \\
\hline & & & Pontoscolecidae & Pontoscolex & P. corethrurus & $N A$ & 1989 & $N A$ & 1 \\
\hline \multirow{14}{*}{ Arthropoda } & \multirow{11}{*}{ Insecta } & Blattodea & NI & NI & NI & 2 & 357 & 0 & 3 \\
\hline & & Colembola & NI & NI & NI & 2 & 5 & 0 & 2 \\
\hline & & Coleoptera & NI & NI & NI & 5 & 499 & 4 & 31 \\
\hline & & Dermaptera & NI & NI & NI & 4 & 59 & 2 & 7 \\
\hline & & Diptera & NI & NI & NI & 1 & 40 & 0 & 0 \\
\hline & & Hemiptera & NI & NI & NI & 1 & 4 & 0 & 1 \\
\hline & & Homoptera & NI & NI & NI & 2 & 21 & 0 & 0 \\
\hline & & Hymenoptera & Formicidae & NI & NI & 6 & 1155 & 2 & 30 \\
\hline & & Isoptera & NI & NI & NI & 1 & 6 & 1 & 16 \\
\hline & & Orthoptera & NI & NI & NI & 4 & 117 & 1 & 7 \\
\hline & & Thysanoptera & NI & NI & NI & 2 & 6 & 0 & 0 \\
\hline & Chelicerata & Anarea & NI & NI & $\mathrm{NI}$ & 5 & 268 & 2 & 9 \\
\hline & \multirow{2}{*}{ Myriapoda } & Chilopoda & NI & NI & NI & 4 & 294 & 1 & 6 \\
\hline & & Diplopoda & NI & NI & NI & 4 & 146 & 1 & 8 \\
\hline Mollusca & Gasteropa & $\mathrm{NI}$ & NI & NI & NI & 2 & 64 & 1 & 12 \\
\hline
\end{tabular}

Results showed no effect of type of fertilizers on soil macroinvertebrate parameters, nor on plant variables (Table 2,3). Contrary to what was expected, abundance and diversity of macroinvertebrates were not higher in organic treated soils, neither in soils under secondary forest. However, there were significant differences between soil type in most parameters and in cycles in some parameters (Table 2,3).

Soil macroinvertebrate morphospecies, biomass and density. The number of morphospecies among type of management systems range from 2.37 to 3.19 , both mean values belonging to chemical fertilizer formulas, while filter mud, vinasse, control and secondary forest had 2.44, 2.87, 3.00 and 3.07 mean values, respectively. The number of morphospecies for Cambisol (2.62) was significantly different to Fluvisol (3.18) and there were no significant differences between cycles; cycle 1, 2.70 and cycle 2, 3.03 (Table 2). 
Table 2. Mean values \pm standard deviation comparison of soil macroinvertebrate parameters and yield for plots with different fertilizer and management system, soil type and cycle (n).

\begin{tabular}{|c|c|c|c|c|c|c|c|c|}
\hline $\begin{array}{c}\text { Treatment* } \\
\text { (16) }\end{array}$ & $\begin{array}{c}\text { Arthropoda } \\
\text { Mollusca } \\
\text { Biomass } \\
\left(\mathbf{g} . \mathbf{m}^{2}\right) \\
\end{array}$ & $\begin{array}{c}\text { Earthworm } \\
\text { Biomass } \\
\left(\mathbf{g . m} \mathbf{m}^{2}\right)\end{array}$ & $\begin{array}{c}\text { Arthropoda } \\
\text { Mollusca } \\
\text { Density } \\
\left(\mathbf{g . m} \mathbf{m}^{2}\right) \\
\end{array}$ & $\begin{array}{c}\text { Earthworm } \\
\text { Density } \\
\left(\mathbf{g} \cdot \mathbf{m}^{2}\right)\end{array}$ & $\begin{array}{l}\text { Number } \\
\text { Morpho } \\
\text { spp }\end{array}$ & $\begin{array}{c}\text { Shannon_- } \\
\exp \\
\exp (\mathbf{H})\end{array}$ & $\begin{array}{c}\text { Soil quality } \\
\text { index }\end{array}$ & $\begin{array}{l}\text { Yield } \\
\left(t^{h} \mathbf{h a}^{-1}\right)\end{array}$ \\
\hline Control & $1.96 \pm 2.44$ & $1.68 \pm 4.72$ & $128.0 \pm 118.7$ & $69.0 \pm 82.4$ & $3.00 \pm 1.46$ & $51.1 \pm 100.0$ & $0.02 \pm 0.075$ & $104.1 \pm 28.8$ \\
\hline $0-20-0$ & $0.70 \pm 0.72$ & $1.00 \pm 1.69$ & $97.0 \pm 58.6$ & $70.0 \pm 97.0$ & $3.31 \pm 1.89$ & $230.0 \pm 736.0$ & $0.10 \pm 0.027$ & $95.8 \pm 25.6$ \\
\hline $0-20-100$ & $2.76 \pm 3.91$ & $1.60 \pm 4.07$ & $162.0 \pm 240.5$ & $53.0 \pm 59.5$ & $3.06 \pm 1.57$ & $61.4 \pm 102.5$ & $0.08 \pm 0.022$ & $99.5 \pm 29.8$ \\
\hline $0-0-100$ & $1.59 \pm 2.38$ & $1.86 \pm 2.93$ & $106.0 \pm 81.6$ & $76.0 \pm 67.3$ & $3.19 \pm 1.47$ & $63.4 \pm 102.0$ & $0.00 \pm 0.000$ & $102.7 \pm 34.4$ \\
\hline $40-10-150$ & $0.91 \pm 1.59$ & $1.07 \pm 2.83$ & $68.0 \pm 50.8$ & $68.0 \pm 84.4$ & $2.50 \pm 1.67$ & $87.0 \pm 271.5$ & $0.01 \pm 0.023$ & $106.2 \pm 33.7$ \\
\hline $40-20-50$ & $4.18 \pm 7.99$ & $0.61 \pm 1.08$ & 103. \pm 101.1 & $115.0 \pm 150.8$ & $3.12 \pm 1.82$ & $232.0 \pm 740.0$ & $0.01 \pm 0.055$ & $97.6 \pm 29.8$ \\
\hline $40-30-50$ & $3.47 \pm 8.61$ & $2.76 \pm 5.63$ & $79.0 \pm 52.1$ & $94.0 \pm 113.4$ & $3.06 \pm 1.53$ & $60.0 \pm 102.7$ & $0.04 \pm 0.175$ & $108.8 \pm 33.4$ \\
\hline $80-0-100$ & $0.74 \pm 1.97$ & $2.37 \pm 5.51$ & $78.0 \pm 77.9$ & $115.0 \pm 198.8$ & $2.37 \pm 1.20$ & $23.3 \pm 37.3$ & $0.02 \pm 0.076$ & $102.9 \pm 20.2$ \\
\hline $80-0-0$ & $1.68 \pm 2.28$ & $3.56 \pm 8.18$ & $71.0 \pm 44.9$ & $68.0 \pm 70.5$ & $2.75 \pm 1.39$ & $39.1 \pm 55.7$ & $0.07 \pm 0.208$ & $113.0 \pm 28.2$ \\
\hline $80-20-100$ & $1.10 \pm 1.68$ & $1.09 \pm 2.43$ & $94.0 \pm 84.8$ & $81.0 \pm 131.4$ & $2.81 \pm 1.56$ & $53.2 \pm 100.8$ & $0.08 \pm 0.125$ & $97.1 \pm 28.1$ \\
\hline $80-20-0$ & $1.11 \pm 2.42$ & $4.08 \pm 9.38$ & $68.0 \pm 53.7$ & $72.0 \pm 61.3$ & $2.37 \pm 1.82$ & $49.1 \pm 102.0$ & $0.00 \pm 0.000$ & $103.9 \pm 41.7$ \\
\hline $120-10-50$ & $0.99 \pm 1.59$ & $1.09 \pm 1.97$ & $100.0 \pm 84.6$ & $119.0 \pm 283.5$ & $2.87 \pm 1.20$ & $28.4 \pm 21.9$ & $0.01 \pm 0.057$ & $104.4 \pm 31.4$ \\
\hline Filter mud & $1.96 \pm 2.83$ & $1.78 \pm 5.15$ & $83.0 \pm 71.8$ & $433.0 \pm 1532.0$ & $2.44 \pm 1.50$ & $28.5 \pm 38.6$ & $0.06 \pm 0.140$ & $108.5 \pm 27.4$ \\
\hline Vinasse & $3.68 \pm 6.42$ & $0.87 \pm 1.62$ & $101.0 \pm 93.8$ & $229.0 \pm 667.0$ & $2.87 \pm 1.09$ & $34.1 \pm 47.2$ & $0.01 \pm 0.040$ & $111.4 \pm 34.2$ \\
\hline $\begin{array}{l}\text { Secondary } \\
\text { Forest (30) }\end{array}$ & $1.50 \pm 3.47$ & $0.52 \pm 2.63$ & $82.1 \pm 58.5$ & $4.2 \pm 12.5$ & $3.07 \pm 1.76$ & $80.5 \pm 134.1$ & $0.02 \pm 0.040$ & \\
\hline \multicolumn{9}{|l|}{ Soil } \\
\hline Fluvisol (112) & $2.7 \pm 4.49 \mathrm{a}$ & $2.52 \pm 5.32 \mathrm{a}$ & $129.0 \pm 123.0 \mathrm{a}$ & $205.0 \pm 639.0 \mathrm{a}$ & $3.18 \pm 1.50 \mathrm{a}$ & $82.0 \pm 359.0 \mathrm{a}$ & $0.05 \pm 0.160 \mathrm{a}$ & $98.4 \pm 20.9 b$ \\
\hline Cambisol (142) & $1.21 \pm 3.60 \mathrm{~b}$ & $0.99 \pm 3.69 \mathrm{~b}$ & $66.7 \pm 51.7 \mathrm{~b}$ & $26.1 \pm 39.8 b$ & $2.62 \pm 1.54 \mathrm{~b}$ & $67.0 \pm 129.0 \mathrm{a}$ & $0.02 \pm 0.100 \mathrm{~b}$ & $109.7 \pm 36.8 \mathrm{a}$ \\
\hline \multicolumn{9}{|l|}{ Cycle } \\
\hline $1(127)$ & $1.81 \pm 3.24 \mathrm{a}$ & $1.83 \pm 3.86 \mathrm{a}$ & $99.0 \pm 115.0 \mathrm{a}$ & $172.0 \pm 605.0 \mathrm{a}$ & $2.70 \pm 1.54 \mathrm{a}$ & $71.0 \pm 287.0 \mathrm{a}$ & $0.02 \pm 0.100 \mathrm{~b}$ & $82.5 \pm 13.7 b$ \\
\hline $2(127)$ & $1.93 \pm 4.78 \mathrm{a}$ & $1.50 \pm 5.13 \mathrm{a}$ & $88.9 \pm 70.9 \mathrm{~b}$ & $38.2 \pm 47.5 \mathrm{~b}$ & $3.03 \pm 1.53 \mathrm{a}$ & $79.0 \pm 276.0 \mathrm{a}$ & $0.04 \pm 0.160 \mathrm{a}$ & $125.5 \pm 27.0 \mathrm{a}$ \\
\hline
\end{tabular}

The macroinvertebrates belonging to Arthropoda and Mollusca Phylum (hereafter ArthropodaMollusca) biomass ranged from 0.70 to $4.18 \mathrm{~g} . \mathrm{m}^{2}$ and from 0.52 to $4.08 \mathrm{~g} . \mathrm{m}^{2}$ for earthworm biomass. For Arthropoda-Mollusca, the lowest and highest values belonged to chemical fertilizer formulas, the vinasse mean value was $3.68 \mathrm{~g} . \mathrm{m}^{2}$, while for both filter mud and control $1.96 \mathrm{~g} . \mathrm{m}^{2}$, and $1.50 \mathrm{~g} . \mathrm{m}^{2}$ for secondary forest. Earthworm biomass varied as follow; chemical fertilizer $4.08 \mathrm{~g} \cdot \mathrm{m}^{2}$, vinasse $0.87 \mathrm{~g} . \mathrm{m}^{2}$, filter mud 1.78 g. $\mathrm{m}^{2}$, secondary forest $0.52 \mathrm{~g} . \mathrm{m}^{2}$ and control $1.68 \mathrm{~g} . \mathrm{m}^{2}$. Fluvisol had significantly higher biomass than Cambisol in both Arthropoda-Mollusca and earthworm biomass, 2.68-1.22 g.m ${ }^{2}$ and 2.52-0.99 g.m², respectively. And, for cycle 1 and 2 the values were, for Arthropoda-Mollusca biomass; 1.81 and 1.93 g.m ${ }^{2}$ and earthworm biomass 1.83 and $1.50 \mathrm{~g} . \mathrm{m}^{2}$, respectively, although no significant differences were found (Table 2).

For Arthropoda-Mollusca density, chemical fertilizer formulas had the lowest and the highest mean values 0.70 and 1.62 ind. $\mathrm{m}^{2}$, while vinasse, filter mud, secondary forest and control had 101.00, 83.00, 81.1 and 128 ind. $\mathrm{m}^{2}$, respectively. Earthworm density ranged from 4.27 to 433.00 ind. $\mathrm{m}^{2}$, the lowest value belonged to secondary forest and the largest to filter mud. For vinasse and control the densities were 229.00 and 69.00 ind $\mathrm{m}^{2}$, respectively, and for chemical fertilizer varied from 53.00 to 119.00 ind. $\mathrm{m}^{2}$. Fluvisol, with 129.00 and 205.00 ind. $\mathrm{m}^{2}$ was significantly higher than Cambisols 66.70 and 26.10 ind. $\mathrm{m}^{2}$ on Arthropoda-Mollusca and earthworm densities, respectively, while cycle 1 was not significantly different to cycle 2 on Arthropoda-Mollusca density, 99.00-88.90 ind. $\mathrm{m}^{2}$, but significantly different on earthworm density, 172.00-38.20 ind. $\mathrm{m}^{2}$, respectively.

Soil quality index and Shannon_exp diversity index. There were not significant differences among management systems on the soil quality index. In general, all values were extremely low, from 0.001 to 0.10 . The largest mean value was for chemical fertilizer formula $(0.10)$, while vinasse, filter mud, secondary 
forest and control had 0.01, 0.06, 0.02 and 0.02, respectively; Fluvisol (0.05) had significantly higher soil quality index than Cambisol (0.02) ( $\mathrm{p}<0.001$ ); and no differences were observed between cycles (Table 2). The Shannon_exp index (exp H) ranged from 28.5 to 232.0. The largest values were for chemical fertilizer formulas, while for vinasse, filter mud, secondary forest and control, was 34.1, 28.5, 80.5 and 51.1 respectively. No significant differences between soil types and cycles (Table 2).

In the principal component analysis (Figure 3), some soil macroinvertebrate parameters showed correlation to Shannon_exp index and soil quality index: Shannon_exp index with number of morphospecies $\left(r^{2}=0.64, p=0.001\right)$, and soil quality index with earthworm biomass $\left(r^{2}=0.32, p=0.001\right)$. However, when correlations were run separately by management system, it could be identified the high affinity of some management systems with some macroinvertebrate parameters. For example, filter mud with earthworm biomass and density. For filter mud the correlation between soil quality index and earthworm biomass and density was $\mathrm{r}^{2}=0.66, \mathrm{p}<0.001$ and $\mathrm{r}^{2}=0.70, \mathrm{p}<0.00$, respectively. For control the correlation between Shannon_exp index with number of morphospecies was $\mathrm{r}^{2}=0.86, \mathrm{p}<0.001$, and between soil quality index with earthworm biomass $r^{2}=0.98, p<0.001$. And for secondary forest the correlation between soil quality index with earthworm biomass was $\mathrm{r}^{2}=0.99, \mathrm{p}<0.001$, and between Shannon_exp index with ArthropodaMollusca density $\mathrm{r}^{2}=0.52, \mathrm{p}<0.001$.

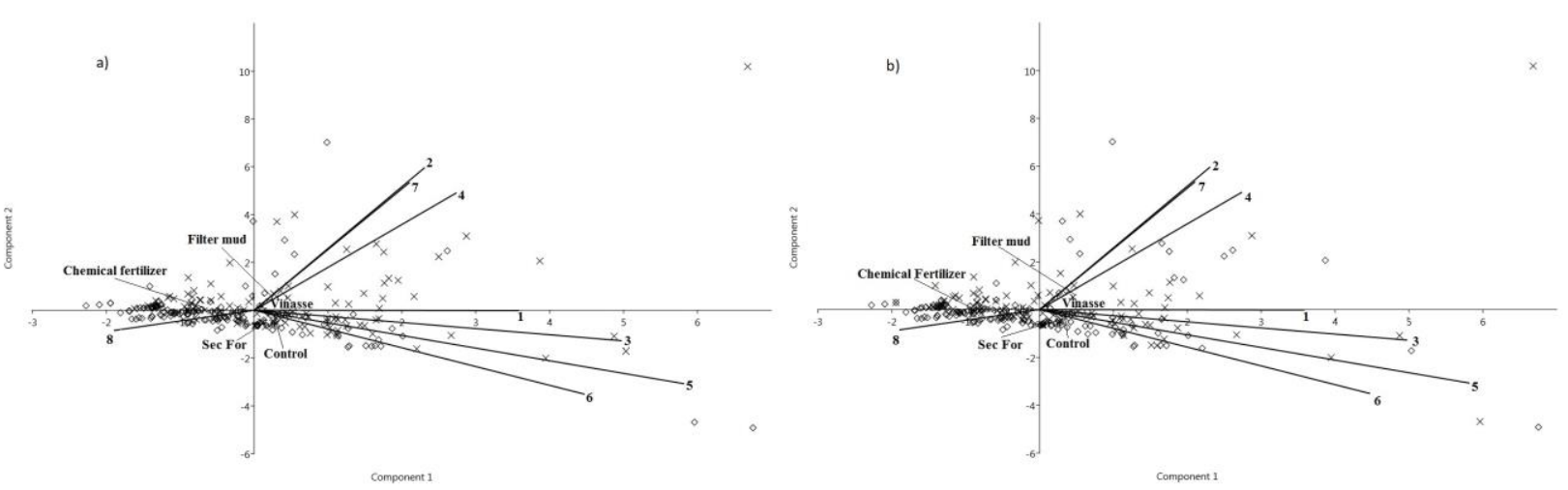

Figure 3. Principal Component (PC) graph for soil macroinvertebrates parameters including treatment, site a) $($ Fluvisol $\times$, Cambisol $\diamond)$ and cycle b) $($ cycle $1 \times$, cycle $2 \diamond) .1=$ Arthropoda-Mollusca biomass $\left(\mathrm{g} \cdot \mathrm{m}^{2}\right), 2=$ Earthworm biomass $\left(\mathrm{g} . \mathrm{m}^{2}\right), 3=$ Arthropoda-Mollusca density (ind. $\left.\mathrm{m}^{2}\right), 4=$ Earthworm density $\left(\right.$ ind. $\left.\mathrm{m}^{2}\right), 5=$ Morphospecies, $6=$ Shannon_exp, $7=$ Soil quality index, $8=$ Yield $\left(\mathrm{t} \mathrm{ha}^{-1}\right)$

Plant macronutrients, yield and plant variables. In general, total nitrogen content was low ranging from $0.13-0.17 \%$, while both phosphorus and potassium content were high with value ranging from 21.04-61.93 $\mathrm{mg} \mathrm{kg}{ }^{-1}$ and $0.45-0.68 \mathrm{cmol} \mathrm{kg}^{-1}$, respectively. Cambisol had significantly higher total nitrogen content $(0.20 \%)$ than the site with Fluvisol soil $(0.12 \%)(\mathrm{p}<0.001)$. With regards to phosphorous content, Cambisol (54.20 mg kg $\mathrm{g}^{-1}$ ) did not differ to Fluvisol (49.90 $\left.\mathrm{mg} \mathrm{kg}^{-1}\right)$. Similarly, to total nitrogen content, Cambisol had higher potassium content than Fluvisol, with $0.99 \mathrm{cmol}(+) \mathrm{kg}^{-1}$ soil compare to $0.35 \mathrm{cmol}(+) \mathrm{kg}^{-1}$ soil, respectively $(\mathrm{p}<0.001)$.

No significant differences were observed among type of fertilizers on yield; yield on chemical fertilizer plots varied between 95.75 and $113.01 \mathrm{t} \mathrm{ha}^{-1}$, while vinasse, filter mud and control had a yield of 111.35, 108.53 and $104.13 \mathrm{t} \mathrm{ha}^{-1}$, respectively (Table 2). Cambisol, as with the $\mathrm{N}$ and $\mathrm{K}$ macroelements, had significantly higher yield $\left(109.70 \mathrm{t} \mathrm{ha}^{-1}\right)$ than Fluvisol $\left(98.40 \mathrm{t} \mathrm{ha}^{-1}\right)$. And cycle $2\left(125.50 \mathrm{t} \mathrm{ha}^{-1}\right)$, had significantly higher yield than cycle $1\left(82.50 \mathrm{t} \mathrm{ha}^{-1}\right)$ (Table 3$)$. 
Moreover, no differences was observed in all plant response variables with regards to type of fertilizers; however, the plants grown in Fluvisol had higher number of stool $\left(2.89 \mathrm{stool} \mathrm{m}^{2}\right)$ and stem length $(195.20 \mathrm{~cm})$ than plants in Cambisol $\left(1.57 \mathrm{stool} \mathrm{m}^{2} ; 171.72 \mathrm{~cm}\right.$ ) respectively, while plants grown in Cambisol had significantly higher number of active leaves (5.82 leaf/plant) than plants in Fluvisol (5.44 leaf/plant) (Table 3). No significant differences were observed between cycles in all plant response variables (Table 3).

Table 3. Mean values ( \pm standard deviation) comparison of some plant response variables between soil type and cycle (n).

\begin{tabular}{cccccc}
\hline Factor & $\begin{array}{c}\text { Number of stool } \\
\left(\mathbf{s t o o l} / \mathbf{m}^{2}\right)\end{array}$ & $\begin{array}{c}\text { Number of } \\
\text { stem }(\mathbf{s t a l k} / \mathbf{m})\end{array}$ & $\begin{array}{c}\text { Number of active } \\
\text { leaves (leaf/plant) }\end{array}$ & $\begin{array}{c}\text { Stem length } \\
(\mathbf{c m})\end{array}$ & $\begin{array}{c}\text { Stem diameter } \\
(\mathbf{c m})\end{array}$ \\
\hline Soil & & & & & \\
Fluvisol (112) & $2.89 \pm 0.73 \mathrm{a}$ & $14.62 \pm 0.11 \mathrm{a}$ & $5.44 \pm 0.02 \mathrm{~b}$ & $195.20 \pm 0.47 \mathrm{a}$ & $7.54 \pm 0.01 \mathrm{a}$ \\
Cambisol (112) & $1.57 \pm 0.58 \mathrm{~b}$ & $15.07 \pm 0.12 \mathrm{a}$ & $5.82 \pm 0.04 \mathrm{a}$ & $171.72 \pm 0.48 \mathrm{~b}$ & $7.58 \pm 0.05 \mathrm{a}$ \\
\hline Cycle & & & & & \\
$1(112)$ & $2.89 \pm 0.73 \mathrm{a}$ & $14.82 \pm 0.11 \mathrm{a}$ & $5.63 \pm 0.03 \mathrm{a}$ & $183.46 \pm 0.15 \mathrm{a}$ & $7.56 \pm 0.01 \mathrm{a}$ \\
$2(112)$ & $2.89 \pm 0.74 \mathrm{a}$ & $14.85 \pm 0.12 \mathrm{a}$ & $5.61 \pm 0.05 \mathrm{a}$ & $183.03 \pm 0.25 \mathrm{a}$ & $7.56 \pm 0.05 \mathrm{a}$ \\
\hline For Soil and Cycle, in columns, means with different lowercase letters are significantly different according to $\mathrm{t}-$ test $(\mathrm{p}<0.05)$.
\end{tabular}

\section{DISCUSSION}

Soil macroinvertebrate morphospecies, biomass and density. Prolonged cultivation of sugarcane at the study area using agronomic practices with different conventional tillage, fertilization and chemical application in mono-cropping system (Chi et al., 2017) seems to have dramatically affected soil ecosystem, specifically on soil macroinvertebrates diversity and abundance. Our study area, including secondary forest harboured low levels of morphospecies, macroinvertebrate mass and density (Table 2). The practice of burning sugarcane fields before and after harvesting destroys organic matter, main source of energy for macroinvertebrates. In an investigation conducted by Chi et al. (2017) in the study area, found that the organic matter of the soil decreased from 35 to $70 \%$ with years (13 to 25) of sugarcane cultivation. In addition, fire kills soil organisms in the immediate zone, further reducing population biomass and density of soil macroinvertebrates (Ramírez et al., 2004, Ramírez et al., 2012).

Jiang et al. (2015) showed that crop residues and organic manure can substantially increase the abundance of macroinvertebrate individuals and communities, with similar positive impact on yields (Gilbert et al., 2008), organic residues from industry are beneficial since they improve soil water conservation and provide a food source for soil macroinvertebrates survival (Deibert \& Utter, 1994). In the present study, filter mud (433.0 ind. $\left.\mathrm{m}^{2}\right)$ and vinasse $\left(229.0\right.$ ind. $\left.\mathrm{m}^{2}\right)$ had the largest and the second largest mean values on earthworm density respectively. In addition, vinasse had the second largest mean value on Arthropoda-Mollusca biomass (3.68 g. $\left.\mathrm{m}^{2}\right)$, however, no significant difference was obtained. Thus, the benefits of organic manure in our study cannot been proven, two years of applying soil organic amendments may be too little to offset the impact of long-lasting sugarcane cultivation. Therefore, studies are required to observe the effect of soil organic amendments on soil invertebrates in sugarcane production in longer observation time (i.e 3-5 years) (Hernández-Melchor et al., 2008).

Lavelle et al. (1994) indicated that in the tropics, earthworms are generally predominant in macroinvertebrate biomass and can have important contribution on soils and crop productivity (Brown $e t$ al., 1999), notwithstanding in the present study earthworms group represented the highest total number of macroinvertebrates (58\%), while Arthropoda-Mollusca (42\%), their abundance and diversity were very low. The three species of annelids identified in the present study, Dichogaster saliens, Dichogaster bolaui and Pontoscolex corethrurus are exotic. On the other hand, exotic earthworms have a high tolerance range to 
extreme management conditions (Fragoso, 2001), since they are influenced by the type of vegetation, management conditions and ecological status of the system. In addition, species richness and presence of certain groups can reveal important information of soil quality (Lavelle, 1996; Klemens, 2003), further indicating perturbation of these ecosystems by conventional management practices (Lavelle \& Spain, 2001). Studies with earthworms on intensified agriculture demonstrate that on annual crops earthworm's specific richness and biomass tend to decrease, with native communities replaced by exotic earthworm (Decaëns \& Jiménez, 2002). The presence of these species possibly follows better adaptation process in these managed ecosystems assuring their survival, since some species of soil macroinvertebrates are comparatively less affected and can respond positively (Lagerlof \& Andren, 1988). For instance, Pontoscolex corethrurus, a geophagous earthworm, is capable of inducing the formation of dense aggregates through the production of casts (Hallaire et al., 2000). This species tend to proliferate very well in disturbed soils due to different macro factors (precipitation, temperature, solar radiation, high reproductive rate) and micro environmental $(\mathrm{pH}$, Organic matter, N, P, S among other), as well as to the diverse management techniques of anthropogenic environments (Fragoso, 2001; Lavelle \& Spain, 2001; Edwards \& Bohlen, 1996).

Many biological communities present a high number of few abundant species under natural conditions (De Ruiter et al., 2002). This concept applies to many communities of soil organisms in tropical ecosystems as indicated by studies on macroinvertebrates (Portilho et al., 2011). In this regard, Siqueira et al. (2016) in a similar study to ours on sugarcane monoculture and two natural vegetation types (Sandbank and Atlantic Forest) in Brazil obtained similar diversity, respectively, suggesting that at the beginning of sugarcane growth, soil macrofauna communities undergo an initial selection and only individuals better adapted to sugarcane management practices and climatic conditions persist (Portilho et al., 2011).

According to Lavelle and Spain (2001) the main groups of soil macrofauna in terms of their abundance and importance of their activities in soil are earthworms, termites, ants, millipedes, beetle larvae and adults. In our study, the macroinvertebrate community was found to be almost diverse in terms of orders, more representatives by earthworms, Hymenoptera, Coleoptera, Blattodea, Chilopoda, Araneae and other minors taxa. None the less, ants were the most abundant Arthropoda (1,185 individuals, $37.30 \%)$ in all systems studied since they generally present rapid colony restructuring, wide foraging area, and social organization (Santos et al., 2017). Even with the disruption caused by the use of fire in sugarcane harvesting (burning prior and after), populations of these species were not adversely affected; similar findings were also observed by Araújo et al. (2004). Moreover, ants are considered ecosystem engineers by increasing soil water infiltration due to their tunnels and can provide valuable ecosystem services (Evans et al., 2010, Lavelle \& Spain, 2001) such as building nests on soil and forming small islands with soil organic matter, $\mathrm{N}$ and $\mathrm{P}$, which are important elements for plant growth. The importance of the nests is that they present favorable conditions for soil organic matter (SOM) mineralization since they are more exposed to environmental changes. Similar results were obtained by Portilho et al. (2011) in sugarcane monoculture in Brazil obtaining 36.3\% ant abundance, thus corroborating with result obtained by Santos et al. (2008) in plant canes, where it was evident its predominance, as well as by Siqueira et al. (2016) with 55\%. Even more, it is important to elucidate its use as soil quality bioindicators in highly disturbed areas as they could act as less frequent taxa predators (Andersen \& Majer, 2004; Schmidt et al., 2005; Crepaldi et al., 2014).

Soil quality index and Shannon_exp diversity index. The low number of earthworm species (3), total absence of native earthworm species and reduced presence of litter decomposers, such as Diplopoda, Isopoda, Coleoptera, Heteroptera and Orthoptera in the study area explain the low soil quality index observed in our investigation $(0-0.10)$ which is extremely low compared to diverse agroforestry systems (1.00), maize (Zea mays) (0.75), cassava (Manihot sculenta) (0.75), banana (Musa paradisiaca) (0.25), and forests (secondary forest, 30 years) (0.5-0.75) (Huerta et al., 2009; Ramirez et al., 2012). Secondary forest, in our investigation, was not the exception. The history of this land reveals that 15 years in fallow are not enough to recover soil-environmental conditions for macroinvertebrate development after years of sugarcane intense cultivation. The present index can be taken as a good parameter of the ecological health 
of the soils under sugarcane cultivation, however more studies under local sugarcane conditions are required.

The dominance of a few morphospecies in our study confirms the low species diversity, indicating the higher dominance that particular species from the Hymenoptera, Coleoptera, Chelicerata, Dermaptera, Orthoptera, Chilopoda and Diplopoda Order have on the study community (Magurran, 2004); due to initial selection and persistence of better adapted species to varying management practices (Portilho et al., 2011; Cabrera-Dávila et al., 2017).

Plant macronutrients, yield and plant variables. $\mathrm{P}$ and $\mathrm{K}$ presented noticeably high values for all sites and management systems, these result could be attributed to the long-term effect of chemical fertilizer programs used the sugarcane region in Belize (Chi et al., 2017), but not for soil biological properties and N levels which were low in the study area. This residual effect of nutrient through long-term application could be beneficial to macrofauna communities since they can offer stable conditions for these organisms, same as those reported by Jiang et al. (2015), which further demonstrated that balanced fertilization in crops (maizewheat-cotton crop rotation) tended to increase the abundance of soil fauna compared with no fertilizer and unbalanced fertilization such as N, NK, NP and PK. However, this cannot be seen in the present study yet, as the results showed, macroinvertebrate mass, density and diversity were very low.

Overall, yields were high in all experimental plots in comparison to the country's average yield (44 $\mathrm{t} \mathrm{ha}^{-1}$ ), noting the good development of plant variables in turn indicating the potential of efficient management of chemical and organic amendments for the sugarcane region in Belize. However, yield will depend on application rates, orographic characteristics, type of soil, chemical composition of fertilizers, crop type and climatic conditions (Moran-Salazar et al., 2016). The higher yields in Cambisol (109.7 t ha$\left.{ }^{1}\right)$ and in second cycle (first ratoon) (125.50 $\left.\mathrm{t} \mathrm{ha}^{-1}\right)$ compare to Luvisol $\left(98.4 \mathrm{t} \mathrm{ha}^{-1}\right)$ and first cycle $\left(82.5 \mathrm{t} \mathrm{ha}^{-}\right.$ $\left.{ }^{1}\right)$ respectively, could be explain by better soil fertility of Cambisol compare to Luvisol and for cycle 2 compare to cycle 1, better establishment of the plants in the field, i.e. stronger development of roots, better climatic conditions, as well as a possible residual effect of organic amendments.

Finally, the proper management of sugarcane cultivation with the aim of balancing soil quality, plant growth and yield, requires a good understanding of all management practices and soils, due to the adverse effect that sugarcane has on productivity. With increasing pressure on sugar demands in Belize, management practices based on organic principles (filter mud and vinasse) will play a crucial role.

\section{CONCLUSIONS}

Abundance and diversity of soil macroinvertebrates were not higher in organic treated soils, neither in soils under secondary forest. No significant differences among type of fertilizers and secondary forest on all studied macroinvertebrate parameters were found. Fluvisol had higher values in all evaluated soil macroinvertebrate parameters, except Shannon_exp index. Contrasting, Cambisol had higher N and K values and higher yield. These results indicate that soil type, in a two years trial, had higher weight on determine the studied parameters than the different management systems. Differences between cycles in sugarcane yield could be attributed to seasonal climatic conditions (yearly variation) and better establishment of sugarcane plants for the first ratoon.

Finally, further studies are recommended in sugarcane based on organic amendments application that could maximize yields, improve soil biological properties and reduce costs in Belize. 
ACKNOWLEDGEMENTS. The authors are grateful to Francisco Lopez, Post Doctorate Fellow, and Juan Carlos Perez, El Colegio de la Frontera Sur, Unidad Campeche, Mexico, who kindly assisted in the statistical analysis. Scholarship to the first author was provided by the National Council of Science and Technology (CONACyT).

\section{LITERATURE CITED}

Aloma, D. J. (1973) La cachaza como fertilizante de la caña de azúcar. La agricultura de Cuba 1, 51-70.

Andersen, A. N., Majer, J. D. (2004) Ants show the way Down Under: invertebrates as bioindicators in land management. Frontiers in Ecology and the Environment, 2, 291-298. https://doi.org/10.1890/1540-9295(2004)002[0292:ASTWDU]2.0.CO;2

Anderson, J. M., Ingram, J. S. I. (1993) Tropical soil biology and fertility: a handbook of methods. 2nd ed. Wallingford: CAB International, USA, $221 \mathrm{pp.}$

Araújo, M. S., Della Lucia, T. M. C., Picanço, M. C. (2004) Impacto da queima da palhada da cana-deaçúcar no ritmo diário de forrageamento de Atta bisphaerica Forel (Hymenoptera: Formicidae). Revista Brasileira de Zoologia, 2, 33-38. http://dx.doi.org/10.1590/S0101-81752004000100006

Bardgett, R. D., van der Putten, W. H. (2014) Belowground biodiversity and ecosystem functioning. Nature, 515, 505-511. https://doi.org/10.1038/nature13855

Baretta, D. (2006) Análise multivariada da fauna edáfica em diferentes sistemas de preparo e cultivo do solo. Pesquisa Agropecuária Brasileira, Brasília, 41, 1675-1679. https://doi.org/10.1590/S0100-204X2006001100014

Barnes, A., Weigelt, P., Jochum, M., Ott, D., Hodapp, D., Haneda, N., Brose, U. (2016) Species richness and biomass explain spatial turnover in ecosystem functioning across tropical and temperate ecosystems. Philosophical Transactions of the Royal Society B 371, 20150279. https://doi.org/10.1098/rstb.2015.0279

Barrios, E. (2007) Soil biota, ecosystem services and land productivity. Ecological Economics, 64, 269285.

https://doi.org/10.1016/j.ecolecon.2007.03.004

Barros, E., Pashanasi, B., Constantino, R., Lavelle, P. (2002) Effects of land-use system on the soil macrofauna in western Brazilian Amazonia. Biology and Fertility of Soils, 35, 338-347. https://doi.org/10.1007/s00374-002-0479-z

Bautista, F., Cram-Heydrich, S., Sommer-Cervantes, I. (2011) Suelos. Pp: 227-258. In: F. BautistaZúñiga, J. L. Palacio-Prieto, H. Delfín-González (Eds.). Técnicas de muestreo para manejadores de recursos naturales: México. Universidad Nacional Autónoma de México, Centro de Investigaciones en Geografía Ambiental, México.

Benazzi, E., Bianchi, M., Fernandes, M., Lima, E., Zonta, E. (2013) Impacts of harvesting methods of sugar cane on the soil macrofauna in production area in Espírito Santo - Brazil. Semina. Ciências Agrárias, Londrina, 34, 3425-3442. http://dx.doi.org/10.5433/1679-0359.2013v34n6Sup11p3425

Blouin, M., Hodson, M. E., Delgado, E. A., Baker, G., Brussaard, L., Butt, K. R., Dai, J., Dendoovenh, L., Peres, G., Tondoh, J. E., Cluzeau, D., Brun, J. J. (2013) A review of earthworm impact on soil function and ecosystem services. European Journal of Soil Science, 64, 161-182. https://doi.org/10.1111/ejss.12025

Brown, G. G., Pashanasi, B., Villenave, C., Patron, J. C., Senapati, B. K., Giri, S., Barois, I., Lavelle, P., Blanchart, E., Blakemore, R. J., Spain, A. V., Boyer, J. (1999) Effects of earthworms on plant production in the tropics. Pp. 87-147. In: P. Lavelle, L. Brussaard, P. F. Hendrix (Eds.). Earthworm management in tropical agroecosystems. CAB International, Wallingford, UK. 
Cabrera, G., Robaina, N., Ponce de León, D. (2011) Riqueza y abundancia de la macrofauna edáfica en cuatro usos de la tierra en las provincias de Artemisa y Mayabeque, Cuba. Pastos y Forrajes, 34, 313-330.

Cabrera-Dávila, G., Socarrás-Rivero, A., Hernández-Vigoa, G., de León-Lima, D., Menéndez-Rivero, Y., Sánchez-Rondón, J. (2017) Evaluación de la macrofauna como indicador del estado de salud en siete sistemas de uso de la tierra, en Cuba. Pastos y Forrajes, 40, 118-126.

CATS (2012) La cachaza y su empleo como abono orgánico en plantaciones de caña de azúcar. Central Azucarera Tempisque S.A (CATS), Guanacaste, Costa Rica, 4 pp.

Chi, L., Mendoza-Vega, J., Huerta, E., Álvarez, D. (2017) Effect of long-term sugarcane (Saccharum spp.) cultivation of chemical properties of soil in Belize. Communications in soil science and plant analysis, 48, 741-755. https://doi.org/10.1080/00103624.2016.1254794

Cifuentes, R., De León, R., Porres, C. (2011) Producción de abono orgánico a partir de cachaza y tallos de caña de azúcar recuperados de las carreteras. Revista de la Universidad del Valle de Guatemala, $23,8-17$.

Correia, M. E., Oliveira, L. C. M. (2000) Soil fauna: General and methodological aspects. Seropédica, Embrapa Agrobiologia, Brazil, 46 pp.

Crepaldi, R. A., Portilho, I. I. R., Silvestre, R., Mercante, F. M. (2014) Formigas como bioindicadores da qualidade do solo em sistema integrado lavoura-pecuária. Ciência Rural, 44, 781-787.

De León, M., González, R. (2011) Informe del estudio de suelo para recomendaciones de fertilizantes en el área cañera de la BSCFA en Belice. Tecnoazúcar, La Habana, Cuba, 95 pp.

De Ruiter, P. C., Griffiths, B., Moore, J. C. (2002) Biodiversity and stability in soil ecosystems: patterns, processes and the effects of disturbance. Pp. 102-113. In: M. Loreau, S. Naeem, P. Inchausti (Eds.). Biodiversity and ecosystem functioning. Synthesis and perspectives. Oxford University Press, Oxford.

Decaëns, T., Jiménez, J. J. (2002) Earthworms communities under an agricultural intensification gradient in Colombia. Plant and Soil, 240, 133-143. https://doi.org/10.1023/A:1015844610604

Deibert, E. J., Utter, R. A. (1994) Earthworm Populations Related to Soil and Fertilizer Management Practices. Better Crops/Summer, 78, 9-11.

Dotaniya, M. L., Datta, S. C., Biswas, D. R., Dotaniya, C. K., Meena, B. L., Rajendiran, S., Regar, K. L., Lata, M. (2016) Use of sugarcane industrial by-products for improving sugarcane productivity and soil health. International Journal of Recycling of Organic Waste Agriculture, 5 (2), 1-10. https://doi.org/10.1007/s40093-016-0132-8

Driessen, P. M., Dudal, R. (1989) Lecture notes on the geography, formation, properties and use of the major soils of the world. Agricultural University Wageningen, Netherlands and Catholic University of Leuven, Belgium, 295 pp.

Edwards, C. A., Bohlen, P. J. (1996) Biology and Ecology of Earthworms. Third edition. Chapman \& Hall, London, UK, $407 \mathrm{pp}$.

Evans, A. T., Dawes, T., Ward, P., Lo, N. (2010) Ants and termites increase crop yield in a dry climate. Nature communications, 2 (262), 1-7. https://doi.org/10.1038/ncomms 1257

Fragoso, C. (2001) Las lombrices de tierra de México (Annelida, Oligochaeta): diversidad, ecología y manejo. Acta Zoológica Mexicana (nueva serie), 1, 131-171.

García, E. (2004) Modificaciones al Sistema de clasificación climática de Köppen. Serie de libro No. 4. Quinta edición, Instituto de Geografía, México, 98 pp.

Gardi, C., Tomaselli, M., Parisi, V., Petraglia, A., Santini, C. (2002) Soil quality indicators and biodiversity in northern Italian permanent grasslands. European Journal of Soil Biology, 38, 103110.

https://doi.org/10.1016/S1164-5563(01)01111-6 
Geissen, V., Sánchez-Hernández, R., Kampichler, C., Ramos-Reyes, R., Sepulveda-Lozada, A., Ochoa-Goana, S., de Jong, B. H. J., Huerta-Lwanga, E., Hernández-Daumas, S. (2009) Effects of land use change on some properties of tropical soils - an example from Southeast Mexico. Geoderma 151, 87-97. https://doi.org/10.1016/j.geoderma.2009.03.011

Ghulam, S., Khan, M. J., Usman, K., Ullah, S. (2012) Effect of different rates of press mud on plant growth and yield of lentil in calcareous soil. Sarhad Journal of Agriculture, 28 (2), 249-252.

Gibb, T., Oseto, Y. (2006) Arthropod Collection and Identification: Field and Laboratory Techniques. Academic Press, 311 pp.

Gilbert, R. A., Morris, D. R., Rainbolt, C. R, McCray, J. M., Perdomo, R. E., Eiland, B., Powell, G., Montes, G. (2008) Sugarcane response to mill mud, fertilizer, and soybean nutrient sources on a sandy soil. Agronomy Journal, 100 (3), 845-854. https://doi.org/10.2134/agronj2007.0247

Gupta, N., Tripathi, S., Balomajumder, C. (2011) Characterization of press mud: a sugar industry waste. Fuel, 90 (1), 389-394. https://doi.org/10.1016/j.fuel.2010.08.021

Hallaire, V., Curmi, P., Duboisset, A., Lavelle, P., Pashanasi, B. (2000) Soil structure changes induced by the tropical earthworm Ponstoscolex corethrurus and organic inputs in a Peruvian ultisol. European Journal of Soil Biology, 36, 35-44. https://doi.org/10.1016/S1164-5563(00)01048-7

Hernández-Melchor, G., Salgado, G. S., Palma, L. D., Lagunes-Espinoza, L., Castelán, E. M., Ruiz R. O. (2008) Vinaza y composta de cachaza como fuente de nutrientes en caña de azúcar en un gleysol mólico de Chiapas, México. Interciencia, 33 (11), 860-855.

Huerta, E., Fragoso, C., Rodriguez-Olan, J., Evia-Castillo, I., Montejo-Meneses, E., De la CruzMondragon, M., Garcia-Hernandez, R. (2006) Presence of exotic and native earthworms in principal aground natural systems in Central and Southeastern Tabasco, Mexico. Caribbean Journal of Science, 42, 359-365.

Huerta, E., Kampichler, C., Geissen, V., Ochoa-Gaona, S., Ben de Jong., Hernández-Daumás, S. (2009) Towards an ecological index for tropical soil quality based on soil macrofauna. Pesquisa Agropecuária Brasileira, 44 (8), 1056-1062. https://doi.org/10.1590/S0100-204X2009000800039

Huerta, E., Rodríguez-Olán, J., Evia-Castillo, I., Montejo-Meneses, E., Cruz-Mondragón, M., GarcíaHernández, R. (2008) Relación entre la fertilidad de suelo y su población de macroinvertebrados. Terra Latinoamericana, 26 (2), 171-181.

James, W. S. (1994) An illustrated key to the earthworms of the Samoan Archipelago (Oligochaeta: Glossoscolecidae, Megascolecidae, Moniligastridae). Micronesica, 37 (1), 1-13.

Jiang, M., Wang, X., Liusui, Y., Sun, X., Zhao, C., Liu, H. (2015) Diversity and abundance of soil animals as influenced by long-term fertilization in Grey Desert Soil, China. Sustainability, 7, 10837-10853. https://doi.org/10.3390/su70810837

Jones, C. G., Lawton, J. H., Shachak, M. (1994) Organisms as ecosystem engineers. Oikos, 69, 373-386. https://doi.org/10.2307/3545850

Jost, L. (2006) Entropy and diversity. Oikos, 113, 363-375. https://doi.org/10.1111/j.2006.0030-1299.14714.x

King, R. B., Baillie, I. C., Abell, T. M. B., Dunsmore, J. R., Gray, D. A., Pratt, J. H., Versey, H. R., Wright, A. C. S., Zisman, S. A. (1992) Land resource assessment Northern Belize. Natural Resources Institute Bulletin, UK, 43, 513 pp.

Klemens, E., Stierhof, T., Dauber, J., Kreimes, K., Wolters, V. (2003) On the quality of soil biodiversity indicators: abiotic and biotic parameters as predictors of soil faunal richness at different spatial scales. Agriculture, Ecosystems and Environment, 98, 273-283.

https://doi.org/10.1016/S0167-8809(03)00087-2 
Lagerlof, J., Andren, O. (1988) Abundance and activity of soil mites (Acari) in four cropping systems. Pedobiologia, 32, 129-145.

Lang-Ovalle, F., Pérez-Vázquez, A., Martínez-Dávila, J., Platas-Rosado, D., Ojeda-Enciso, L., González-Acuña, I. (2010) Macrofauna edáfica asociado a plantaciones de mango y caña de azúcar. Terra Latinoamericana, 29, 169-177.

Lavelle, P. (1996) Diversity of soil fauna and ecosystem function. Biology International, 33, 3-16.

Lavelle, P., Blanchart-Martin, A., Spain, A. V., Martin, S. (1994) Impact of soil fauna on the properties of soils in the humid tropics. Pp: 157-185. In: R. Lal, P. A. Sanchez (Eds.). Myths and science of soils in the tropics. Special Publication 29. Soil Science Society of America. Madison, WI, USA.

Lavelle, P., Decaëns, T., Aubert, M., Barot, S., Blouin, M., Bureau, F., Margerie, P., Mora, P., Rossi, J. P. (2006) Soil invertebrates and ecosystem services. European Journal of Soil Biology, 42, 3-15. https://doi.org/10.1016/j.ejsobi.2006.10.002

Lavelle, P., Spain, A. V. (2001) Soil Ecology. Kluwer Scientific Publications, Amsterdam.

López, A. R., Faria, C., Prieto-Fernández, A., Trasar-Cepeda, C., Manaia, C. M., Nuñes, O. C. (2011) Comparative study of the microbial diversity of bulk paddy soil of two rice fields subjected to organic and conventional farming. Soil Biology \& Biochemistry, 43, 115-125. https://doi.org/10.1016/j.soilbio.2010.09.021

Magurran, E. A. (2004) Measuring Biological Diversity. Blackwell, Oxford, UK, 256 pp.

Malézieux, E., Crozat, Y., Dupraz, C., Laurans, M., Makowski, D., Ozier-Lafontaine, H., Rapideli, B., de Tourdonnet, S., Valantin-Morison, M. (2009) Mixing plant species in cropping systems: concepts, tools and models. A review. Agronomy for Sustainable Development, 29, 43-62. https://doi.org/10.1051/agro:2007057

Mathieu, J., Rossi, J. P., Mora, P., Lavelle, P., Martins, P., Rounland, C., Grimaldi, M. (2005) Recovery of soil macrofauna communities after forest clearance in Eastern Amazonia, Brazil. Conservation Biology, 19, 1598-1605. https://doi.org/10.1111/j.1523-1739.2005.00200.x

Melchor, G., García, S., Palma, D., Espinoza, L., Estrada, M., Rosado, O. (2008) Vinaza y composta de cachaza como fuente de nutrientes en caña de azúcar en un gleysol molico de Chiapas, México. Interciencia, Caracas, Venezuela, $7 \mathrm{pp}$.

Minitab Inc (2010) Minitab Reference Manual PC version Release 17, State College, PA: Minitab, Inc.

Mojica, F., González, N., León, S. (1994) La agricultura orgánica en Costa Rica. Pp. 45-60. In: Simposio Centroamericano sobre Agricultura Orgánica. UNED, San José, Costa Rica.

Moran-Salazar, R. G., Sanchez-Lizarraga, A. L., Rodriguez-Campos, J., Davila-Vazquez, G., Marino-Marmolejo, E. N., Dendooven, L., Contreras-Ramos, S. M. (2016) Utilization of vinasses as soil amendment: consequences and perspectives. Springer Plus 5, (1).

Mummey, D. L., Stahl, P. D., Buyer, J. S. (2002) Microbial biomarkers as an indicator of ecosystem recovery following surface mine reclamation. Applied Soil Ecology, 21, 251-259. https://doi.org/10.1016/S0929-1393(02)00090-2

Neugebaver, B., Ahumada, M., Buch, R. (1992) Agricultura ecológicamente apropiada. Fundación Alemana para el Desarrollo Integral (DSE), Alemania, $185 \mathrm{pp}$.

Norma Oficial Mexicana (2002) NOM-021-RECNAT. Especificaciones de fertilidad, salinidad y clasificación de suelos. Estudios, muestreo y análisis. Secretaría de Medio Ambiente y Recursos Naturales, $73 \mathrm{pp}$.

Olsen, S. R., Sommers, L. E. (1982) Phosphorus. Pp: 403-429. In: A. L. Page, D. R. Keeney, D. E. Baker, R. H. Miller, E. Roscoe, J. D. Rhoades (Eds.). Methods of soil analysis, Part 2. Chemical and Microbiological Properties. Agronomy Monograph No. 9 (Second edition).

Paoletti, M. G. (1999) The role of earthworms for assessment of sustainability and as bioindicators. Agriculture, Ecosystems and Environment, 74, 137-155. https://doi.org/10.1016/S0167-8809(99)00034-1

Pasqualin, L., Dionísio, J., Zawadneak, M., Marçal., C. (2012) Macrofauna edáfica em lavouras de canade-açúcar e mata no noroeste do Paraná - Brasil. Ciências Agrárias, Londrina, 33 (1), 7-18. 
https://doi.org/10.5433/1679-0359.2012v33n1p7

Portilho, I., Borges, C. D., Costa, A. R., Salton, J. C., Mercante, F. M. (2011) Residues of sugarcane crop and its effects on the epigeic invertebrate fauna. Semina, 32 (3), 959-970.

http://dx.doi.org/10.5433/1679-0359.2011v32n3p959

Prado, P., Jaramillo, L. (2006) Estudio de la factibilidad para el uso de la cachaza generada a partir del proceso de la caña de azúcar como abono. Tesis. Universidad de la Sabana, Colombia, 167 pp.

Prado, R., Caione, G., Silva, C. (2013) Filter cake and vinasse as fertilizers contributing to conservation agriculture. Applied and Environmental Soil Science, 581984, 8. http://dx.doi.org/10.1155/2013/581984

Ramírez, M., Armbrecht, I., Enríquez, M. (2004) Importancia del manejo agrícola para biodiversidad: caso de las hormigas en caña de azúcar. Revista Colombiana de Entomología, 30 (1), 115-123.

Ramírez, M., Chará, J., Pardo-Locarno, L. C., Montoya-Lerma, J., Armbrecht, I., Molina, C. H., Molina, E. J. (2012) Biodiversidad de hormigas hipógeas (Hymenoptera: Formicidae) en agroecosistemas del Cerrito, Valle del Cauca. Livestock Research for Rural Development, 24 (15).

Rodríguez, A. (1994) Validación de un Sistema de producción ecológica para cultivos de invernadero. Escuela Agroecologica. Caritas-Uruguay, Pronappa-FIDA, 17 pp.

Rossetto, R., Dias, F. L., Vitti, A. C., Cantarella, H., Landell, M. G. (2008) Manejo conservacionista e reciclagem de nutrientes em cana-de-açúcar tendo em vista a colheita mecánica. Informaçóes Agronomicas, 124, 8-13.

Ruiz-Camacho, N. (2004) Mise au point d'un système de bioindication de la qualité du sol base sur l'étude des peuplements de macro-invertébrés. Thesis (PhD) Université Paris VI, Paris, 270 pp.

Santos, L. A. O., Guevara, N. N., Fernandes, O. A. (2017) Diversity and abundance of edaphic arthropods associated with conventional and organic sugarcane crops in Brazil. Florida Entomologist, 100 (1), 134-144.

https://doi.org/10.1653/024.100.0119

Santos, G. G., Silveira, P. M., Marchäo, R. L., Becquer, T., Balbino, L. C. (2008) Macrofauna edáfica associada a plantas de cobertura em plantio direto em um Latossolo Vermelho do Cerrado. Pesquisa Agropecuária Brasileira, Brasília, 43 (1), 115-122. https://doi.org/10.1590/S0100-204X2008000100015

Schmidt, M. H., Roschewitz, I., Thies, C., Tscharntke, T. (2005) Differential effects of landscape and management on diversity and density of ground-dwelling farmland spiders. Journal of Applied Ecology, 42, 281-287.

https://doi.org/10.1111/j.1365-2664.2005.01014.x

Shukla, M. K., Lal, R., Ebinger, M. (2006) Determining soil quality indicators by factor analysis. Soil \& Tillage Research, 87, 194-204.

https://doi.org/10.1016/j.still.2005.03.011

Siqueira, G. M., Silva, E. F., Moreira, M. M., Santos, G. A., Silva, R. A. (2016) Diversity of soil macrofauna under sugarcane monoculture and two different natural vegetation types. African Journal of Agricultural Research, 11 (30), 2669-2677.

https://doi.org/10.5897/AJAR2016.11083

Statistical Institute of Belize (2015) Estimated mid-year population 2015 and merchandize trade, population and household. Book Green, London: Halcrow Group Limited, 48 pp.

Stiling, P. (1999) Ecology: theories and applications. 3rd ed. Prentice Hall, New Jersey, 638 pp.

Subbler, S., Edwars, C. A., Metzger, J. (1998) Comparing vermicompost and composts. BioCycle, 39, 63-66.

Sugar Cane Production Committee (SCPC) (2015) Sugar Industry Control Board. Report of crop cycle 2014-2015. Orange Walk, Belize, 18 pp.

Vandevivere, P., Ramírez, C. (1995) Control de calidad de abonos orgánicos por medio de bioensayos. Pp: 121-140. En: J. A. García, J. M. Najera (Eds.). Memoria Simposio Centroamericano de Agricultura Orgánica. San José, Costa Rica. 
Velasquez, E., Lavelle, P., Andrade, M. (2007) GISQ, a multifunctional indicator of soil quality. Soil Biology and Biochemistry, 39 (12), 3066-3080.

https://doi.org/10.1016/j.soilbio.2007.06.013

Williams, G. (1987) Techniques and fieldwork in ecology. Bell-Hyman, Great Britain, $160 \mathrm{pp}$.

WRB (2014) International Soil Classification System for naming soils and creating legends for soil map. World Soil Resources Report 106, Rome, 192 pp. 